\author{
モード拡張法を組み込んだ補強リブ構造変更 \\ シミュレーション* \\ 鞍 谷文 保*1, 島田哲 夫*2 \\ 山野 惟 ${ }^{* 3}$, 小川武 範*4

\section{Structural Modification Procedure with Mode Shape Expansion for Rib Stiffeners} \\ Fumiyasu KURATANI*5, Tetsuo SHIMADA, \\ Tadao YAMANO and Takenori OGAWA \\ ${ }^{* 5}$ Faculty of Education, Wakayama University, \\ 930 Sakaedani, Wakayama-shi, Wakayama, 640-8510 Japan

\begin{abstract}
This paper proposes a procedure for predicting the modal data of a thin plate structure with a rib stiffener even when the rib is attached to any location where mode shapes are not measured. The proposed procedure is based on the structural dynamics modification (SDM) method and the mode shape expansion method is incorporated to estimate the mode shape data at the unmeasured points. In the expansion process, a submodel for the area where the ribs will be attached is used instead of the whole structure model. Numerical results from a plate structure with the two L-shaped ribs show that the proposed procedure produces the accurate predictions of the modal data using the estimated mode shape data at the unmeasured points. In addition, the mode shape data is estimated accurately from the submodel with free boundary condition. Furthermore, the proper number of analysical modes to be combined in the expansion process can be determined from the condition number of the modal matrix of the submodel.
\end{abstract}

Key Words: Modal Analysis, Finite Element Method, Measurement, Structural Dynamics Modification, Mode Shape Expansion, Rib Stiffener, Condition Number, Boundary Condition

\begin{abstract}
1. 緒
薄板構造物の振動・騷音を低減するために, 補強リ ブを取り付けるリブ構造化が行われている. リブ構造 化においては，適正なりブ配置やリブ寸法を定める必 要があり,そのためにリブ補強後の振動特性を簡易に 予測する方法が求められている.

リブ補強後の振動特性を再解析や再実験なしに簡 易に予測する方法として, SDM（Structural Dynamics Modification）法(1)を基礎とした構造変更シミュレーシ ヨンがある(2)(3)。この方法は, 有限要素法 (FEM) 解 析や実験モード解析で得られた補強前の薄板構造物の モード特性（固有振動数, 振動モード）と補強リブの 質量・剛性行列だけから補強後のモード特性を予測す る. 予測精度を向上させるために, FEM 解析で用い られるシェル要素を導入し, リブ形状や取付け状態を 正確にモデル化することが試みられた(4). しかし, 補

\footnotetext{
* 原稿受付 2004 年 9 月 17 日.

*1 正員, 和歌山大学教育学部 (\$640-8510 和歌山市栄谷 930).

*2 正員, 和歌山大学システム工学部.

*3 兵庫教育大学学校教育学部 ( $673-1494$ 兵庫県加東郡社町 下久米 942-1).

*4 正員, 兵庫教育大学学校教育学部.

E-mail : kuratani@center.wakayama-u.ac.jp
}

強前のモード特性として実験デー夕を用いた場合には, センサなどの問題でリブ取付け点における回転自由度 データが利用できないため, 予測精度が悪くなった. そこで前報(5)では，モード拡張法を導入し，実験デー 夕として利用可能な回転自由度データを推定すること で予測精度を向上させた。

しかし, リブ配置の最適化を検討するためには, リ ブ取付け位置が測定点だけに制限されることは問題で ある. また前報では，モード拡張法を SDM 法に組み 込む上での検討が不十分であった.

そこで本報では, 前報を拡張し, 補強リブが測定点 以外の位置に取り付けられた場合でも, 補強後のモ一 ド特性の予測が可能な補強りブ構造変更シミュレーシ ヨン法を提案する. そのために, モード昖張法を用い て測定点以外のリブ取付け位置での実験デー夕を推定 する.ここで導入するモード拡張法は，リブ取付け候 補領域だけをモデル化した部分モデルの振動モードの 重ね合せとして実験デー夕を推定するので, 重ね合せ るモードの数を与える必要がある. そこで, 推定精度 が高くなるときの重ね合せるモードの数を決定するた めの指標を提示する. 基礎的検討として, 数值例によ り提案方法の有用性を検証するとともに, 部分モデル の境界条件の影響についても検討する. 


\section{2. 理 論}

$2 \cdot 1$ 構造変更シミュレーション リブ補強前の 薄板構造物の固有角振動数 $\omega_{r}$ と振動モード $\{\phi\}_{r}$ は, 次式の固有值問題を解くことで求まる.

$$
\left[K^{P}\right]\{\phi\}_{r}-\omega_{r}^{2}\left[M^{P}\right]\{\phi\}_{r}=\{0\}
$$

ここで, $\left[M^{P}\right]$ と $\left[K^{P}\right]$ はそれぞれリブが取り付けら れる前の薄板構造物の質量行列と剛性行列である. 補 強リブを取り付けたリブ補強後の固有角振動数 $\bar{\omega}_{j}$ と 振動モード $\{\bar{\phi}\}_{j}$ は, 式(1)に補強リブの質量行列と剛 性行列を加えた次式の固有值問題を解くことで求まる.

$$
\left(\left[K^{P}\right]+\left[\Delta K^{R}\right]\right)\{\bar{\phi}\}_{j}-\bar{\omega}_{j}^{2}\left(\left[M^{P}\right]+\left[\Delta M^{R}\right]\right)\{\bar{\phi}\}_{j}=\{0\}
$$

ここで, $\left[\Delta M^{R}\right]$ と $\left[\Delta K^{R}\right]$ はそれぞれ補強リブ単体の 質量行列之剛性行列である.

SDM 法を基礎とした構造変更シミュレーション法 (以下, SDM 法と呼ぶ) の利点は, 式(2)の大自由度 の固有值問題を直接解くことなしに, リブ補強後のモ 一ド特性（固有振動数, 振動モード）を予測できるこ とである.SDM 法では, 補強後の薄板構造物の振動 モード $\{\bar{\phi}\}_{j}$ は補強前の振動モード $\{\phi\}_{r}$, 重ね合せで, 次のように表されると仮定する.

$$
\{\bar{\phi}\}_{j}=\sum_{r=1}^{N_{i}} \xi_{r}^{j}\{\phi\}_{r}=[\Phi]\{\xi\}_{j}
$$

ここで， $\xi_{r}^{j}$ は補強前の振動モードを重ね合せるとき の各モードの重みで, $[\Phi]$ と $\{\xi\}_{j}$ はそれぞれモード行 列と重み係数ベクトルである. 補強前の振動モードを モード質量が 1 となるように正規化した後，式(3)を 式(2)に代入する. さらに, 左からモード行列の転置 $[\Phi]^{T}$ を掛けて直交性を考慮することで，次式のモ一 ド座標系の方程式が得られる。

$$
\begin{aligned}
& \left(\left[\omega^{2}\right]+[\Phi]^{T}\left[\Delta K^{R}\right][\Phi]\right)\{\xi\}_{j} \\
& -\bar{\omega}_{j}^{2}\left([I]+[\Phi]^{T}\left[\Delta M^{R}\right][\Phi]\right)\{\xi\}_{j}=\{0\}
\end{aligned}
$$

ここで, $[I]$ は $[\Phi]$ の要素として採用する補強前の振 動モードの数 $N_{s}$ と同じ次元の単位行列で, $\left[\omega^{2}\right]$ は補 強前の固有角振動数 $\omega_{r}$ の二乗を要素とする対角行列 である. リブ補強後の固有角振動数 $\bar{\omega}_{j}$ は, 式(4)の小 自由度の固有値問題を解くことで求まる.

式(4)中の補強前の固有角振動数 $\omega$, と振動モード $\{\phi\}_{r}$ は，式(1)の固有值解析結果だけでなく, 実験モ 一ド解析で抽出された $\omega_{r}$ と $\{\phi\}_{r}$ を用いることができ る. 実験デー夕を用いた構造変更シミュレーションの
特長の一つは，固有振動数の変化を知るだけなら，実 験で測定する振動モードは図1に示すようなリブ取付 け点におけるデータだけでよく, 構造全体の詳細な実 験が必要ないことである. 本報では, 実験で得られた 固有角振動数と振動モードで式(4)を構築することを 前提とする.

$2 \cdot 2$ 補強リブの縮小行列補強リブのモデル化 精度を上げるために, リブを有限要素法（FEM）解 析で用いられるのと同じシェル要素でモデル化すると, 図 1 のように離散化した節点のいくつかは取付け面の 面内にはない.このままでは対応する実験デー夕がな く, 式(4)を構筑できない. そこで前報(5)で述べたよう に, 静縮小法を用いて補強りブの質量行列と剛性行列 を取付け点の自由度に縮小する.ここでは最終的に導 かれた式だけを示すが, 次式で縮小された $\left[\Delta M^{R}\right]$ と $\left[\Delta K^{R}\right]$ が算定できる.

$$
\left.\begin{array}{rl}
{\left[\Delta M^{R}\right]} & =\left[M_{c c}^{R}\right]-\left[M_{c u}^{R} K_{u u}^{R^{-1}} K_{u c}^{R}\right] \\
& +\left[K_{c u}^{R} K_{u u}^{R-1}\right]\left[M_{u u}^{R} K_{u u}^{R-1} K_{u c}^{R}-M_{u c}^{R}\right] \\
{\left[\Delta K^{R}\right]} & =\left[K_{c c}^{R}\right]-\left[K_{c u}^{R} K_{u u}^{R^{-1}} K_{u c}^{R}\right]
\end{array}\right\} \cdots
$$

ここで, 右辺は補強リブの $\left[M^{R}\right]$ と $\left[K^{R}\right]$ の部分行列 で, 添字 $c$ はリブモデルの節点の内, 薄板に取り付く 節点の自由度（結合自由度）を表し, 添字 $u$ はそれ以 外の自由度（未結合自由度）を表す。

$2 \cdot 3$ 部分モデルを用いたモード拡張法 前報で, 補強リブを平面シェル要素でモデル化した場合に, SDM 法の予測精度を向上させるためには, リブ取付 け点における実験データとして回転自由度を含む 6 自 由度のデータが必要であることを示した. そこでモー ド昖張法(6)を導入し, リブ取付け面に垂直な方向の 並進自由度データを参照し，未測定自由度のデータを 推定した．本報では前報を挔張し，測定点だけでなく， 測定点以外のリブ取付け候補点における並進と回転の 自由度データを推定することで, リブが測定点以外の 位置に取り付けられた場合にでも SDM 法による予測

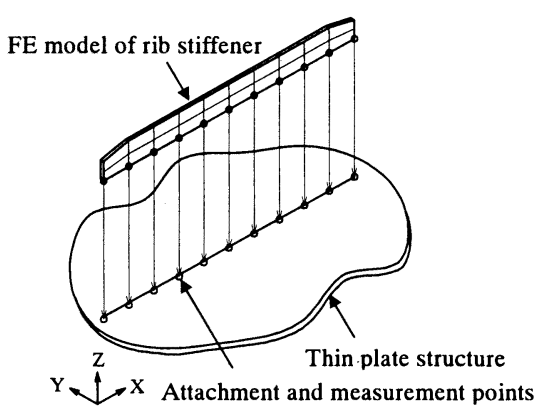

Fig.1 Thin plate structure with a rib stiffener 
を可能とする.

モード拡張法では, 推定しようとする未測定点での 実験データを解析モデルの振動モードの重ね合せで推 定する. その特長は, 推定しようとする未測定点と同 じ節点位置および未測定自由度と同じ自由度を有する 解析モデルがあればよいことで, モデルアップデート などで解析モデルの固有振動数を実験デー夕に合わす 必要はない.この特長を生かし, モード拡張で用いる 解析モデルとして, 構造全体ではなく図 2 に示すよう なリブ取付け候補領域と測定点をモデル化した部分モ デルを用いる. 部分モデルを用いる利点は, モデル化 の容易さと実験の簡素化である.

モード昖張法では, 実験で得られた振動モ一ド（実 験モード）は, 部分モデルの FEM 解析で得られた振 動モード（解析モ一ド）の重ね合せで, 次のように表 されると仮定する.

$$
\left\{\phi^{X}\right\}_{r}=\sum_{i=1}^{N_{e}} \gamma_{i}^{r}\left\{\phi^{A}\right\}_{i}=\left[\Phi^{A}\right]\{\gamma\}_{r}
$$

ここで, $\left\{\phi^{X}\right\}_{r}$ は実験モ一ド, $\left\{\phi^{A}\right\}_{i}$ と $\gamma_{i}^{r}$ はそれぞれ 解析モードと重ね合せるときの各モ一ドの重み, さら に $N_{e}$ は重ね合せる解析モードの数を表す. また, $\left[\Phi^{A}\right]$ と $\{\gamma\}_{r}$ はそれぞれ部分モデルの解析モ一ドを要 素とするモード行列と重み係数べクトルである.

重ね合せる解析モードの重みは, 次のようにして決 める. 式(6)を次式のように, 実際に測定した測定点 における自由度 (測定自由度) と推定しようとする未 測定点における自由度（未測定自由度）に分ける.

$$
\left\{\begin{array}{l}
\phi_{m}^{X} \\
\phi_{u}^{X}
\end{array}\right\}_{r}=\left[\begin{array}{l}
\Phi_{m}^{A} \\
\Phi_{u}^{A}
\end{array}\right]\{\gamma\}_{r}
$$

ここで, 添字 $m$ と $u$ はそれぞれ測定自由度と末測定 自由度を表す. 式(7)の上側の測定自由度に関する式 だけを取り出し

$$
\left\{\phi_{m}^{X}\right\}_{r}=\left[\Phi_{m}^{A}\right]\{\gamma\}_{r}
$$

左から測定自由度だけのモード行列の一般逆行列 $\left[\Phi_{m}^{A}\right]^{+}$を掛けると

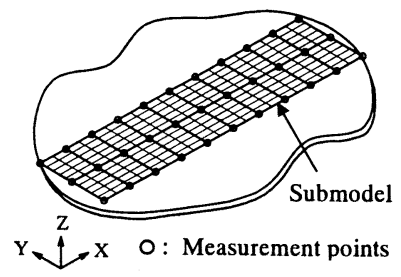

Fig.2 Submodel for the mode shape expansion

$$
\{\gamma\}_{r}=\left[\Phi_{m}^{A}\right]^{+}\left\{\phi_{m}^{X}\right\}_{r}
$$

が得られ，重み係数が求まる. なお,ここでは一般逆 行列として特異值分解による一般逆行列( ${ }^{(8)}$ を用いた.

式(9)を式(7)に代入し整理することで, 実験デー夕 として利用できる未測定自由度のデータと測定自由度 のスムージングされたデータを得るための次式が導か れる.

$$
\left\{\begin{array}{l}
\phi_{m}^{E} \\
\phi_{u}^{E}
\end{array}\right\}_{r}=\left[\begin{array}{ll}
\Phi_{m}^{A} & \Phi_{m}^{A^{+}} \\
\Phi_{u}^{A} & \Phi_{m}^{A^{+}}
\end{array}\right]\left\{\phi_{m}^{X}\right\}_{r}
$$

$2 \cdot 4$ 重ね合せるモード数の決定 モード拡張法 で推定された振動モードデータの精度は, 式(8)で用 いる部分モデルの解析モードの数に影響を受ける. 重 ね合せるモードの数が少なければ, 実際に測定された 振動モードの形状を正確に表すことができず, 推定精 度は悪くなる. 一方, 重ね合せるモードの数を多くし, 測定された振動モ一ドの形状を正確に表そうとすると, 重ね合せるモードの数が測定点数よりも多くなり, 式 (9)において一般逆行列を用いても物理的に意味のあ る一意的な重み係数が求まらない. そこで, 測定点の 状況に応じて適切な重ね合せるモードの数を決めるこ とで, 振動モードデータの推定精度が高くなると考え られる.

本報では, 重ね合せるモ一ドの数を決めるための指 標として, 測定自由度と同じ自由度の解析モ一ドを要 素とする式(8)のモード行列 $\left[\Phi_{m}^{A}\right]$ の条件数を用いる. モード行列の条件数は, 実験モード解析において測定 点や測定位置の適切さを評価する指標 ${ }^{(9)}$, あるいは大 自由度の行列を小自由度の行列に縮小するときの選択 自由度の適切さを評価する指標 ${ }^{(10)}$ として用いられた 例がある. 条件数は, モード行列の特異值分解で得ら れる特異值の最大值 $\mu_{\text {largest }}$ と最小值 $\mu_{\text {smallest }}$ の比とし

て, 次式のように定義される.

$$
\kappa([\Phi])=\frac{\mu_{\text {largest }}}{\mu_{\text {smallest }}}
$$

ここで, モード行列の条件数が 1 に近いなら, 解析モ 一ドは互いに独立で一意的な重み係数が求まる. そこ でモ一ド行列の条件数の変化を眺め, 条件数が余り大 きくならない範囲でなるべく多くのモードを採用すれ ばよいと考えられる. なお条件数を求める場合に，す ベての測定自由度におけるモードデータの值が 0 に近 いモードが含まれると最小特異值が $0 に$ 近くなってし まい, 条件数が正しく評価できない. そこで本報では, あらかじめ測定自由度と同じ自由度のモードデータの 
值がすべて 0 に近いモードをモード行列から取り除い て条件数を求める.

なお，測定点を多くして多くの解析モードを用いる 場合には, 別の問題として振動モードの測定誤差の影 響が現れる. その対策の一つとして, 既報(クで提案し た MAC（Modal Assurance Criterion）值を基に，重ね 合せる解析モードを決定するモード選択法の適用が考 えられる.

$2 \cdot 5$ 計算手順 モード拡張法を組み込んだ補強

リブ構造変更シミュレーションの計算手順をまとめる.

(1) 測定点およびリブ取付け候補点を含む部分モデル を作成し，解析モードを算出する.

(2) 部分モデルで定義した測定点で実験モードを測定 する.

(3) モード拡張でリブ取付け候補点における実験モー ドを推定する.

(4) リブをモデル化し，質量・剛性行列を算定する.

(5) 静縮小で取付け点の自由度に縮小した補強リブの 質量・剛性行列を求める.

(6) 推定した実験モードと縮小した質量・剛性行列か ら SDM 法でリブ補強後のモード特性を予測する.

\section{3. 数 值 例}

提案したモード拡張法を組み込んだ補強りブ構造変 更シミュレーション法の有用性を検証する. 本研究の 目的は実験モ一ドベースの構造変更シミュレーション 法を提案することであるが，本報では数值例で基礎的 検討を行う.

数值例では, 図 3 に示す 2 枚の $\mathrm{L}$ 型鋼を補強りブ として取り付けた薄板構造物を取り上げた．最初に有 限要素法 (FEM) 解析で, 補強リブを取り付ける前 のモード特性と補強リブを取り付けたときのモード特 性を算出した．補強リブを取り付ける前のモード特性 は真の実験データとして, 補強リブを取り付けたとき のモード特性は構造変更シミュレーションの真値とし て用いた. 薄板構造物と補強リブの材料特性は, ヤン グ率 $E=193 \mathrm{GPa}$, ポアソン比 $v=0.3$, 密度 $\rho=7870 \mathrm{~kg} / \mathrm{m}^{3}$ とした. なお FEM 解析においては, 薄 板構造物と補強りブを平面シェル要素でモデル化し, 境界条件は薄板構造物の両下端を完全固定とした.

$3 \cdot 1$ 真の実験データを用いた SDM モード抎 張法で推定した実験デー夕を用いた SDM 法の予測精 度を評価する前に, FEM 解析で得られた真の実験デ 一夕を用いて SDM 予測計算を行う.ここで予測され たモード特性は，モード拡張法で推定した実験デー夕 を用いた SDM 法の予測精度を評価するときに用いる.
ここでは，補強リブ取付け位置ごとに図 3 に示す 21 点で $\mathrm{X}, \mathrm{Y}, \mathrm{Z}$ 方向の並進と軸まわりの回転の 6 自 由度すべてが測定されたと想定した. 各リブは, 平面 シエル要素を用いて $\mathrm{X}$ 方向 20 分割, $\mathrm{Y}$ 方向と $\mathrm{Z}$ 方向 それぞれ 2 分割し，105 節点（21 節点 $\times 5$ 節点）を持 つようにモデル化した. その後 630 自由度（105 節点 $\times 6$ 自由度）の質量・剛性行列を $\mathrm{X}$ 軸に平行なりブ底 面中央の 21 個の節点（結合節点）における 126 自由 度（21 節点 $\times 6$ 自由度）の質量・剛性行列に縮小す ることで, 測定自由度との整合性を図った.SDM 予 測計算は, 補強前の 1 次から 20 次までの 20 個の実験 モードを用いて, リブ取付け間隔 $\mathrm{L}=160 \mathrm{~mm}, 200 \mathrm{~mm}$, $240 \mathrm{~mm}$ の 3 箅所について行った.

図 4 に, 最初の 15 個のモードについて SDM 法に よる固有振動数の予測結果と FEM 解析による再解析 結果の比較を示す. 図において, すべてのリブ取付け 間隔のすべてのモードで予測誤差は 5\%以下である. さらに, 各リブ取付け間隔における 15 モ一ドの約半 分は, 予測誤差が $1 \%$ 程度と小さくなっている. した

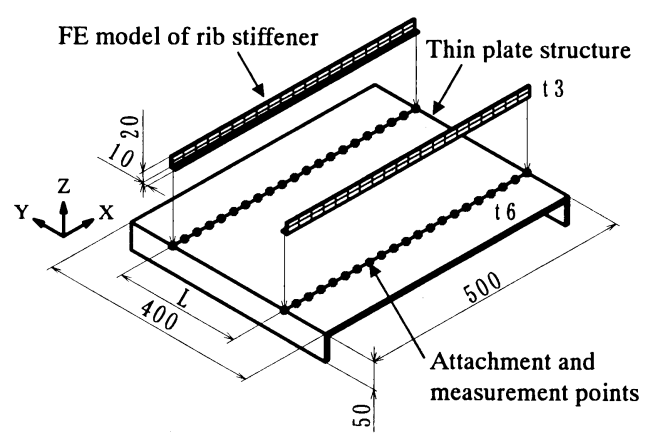

Fig.3 Thin plate structure model with the rib stiffeners

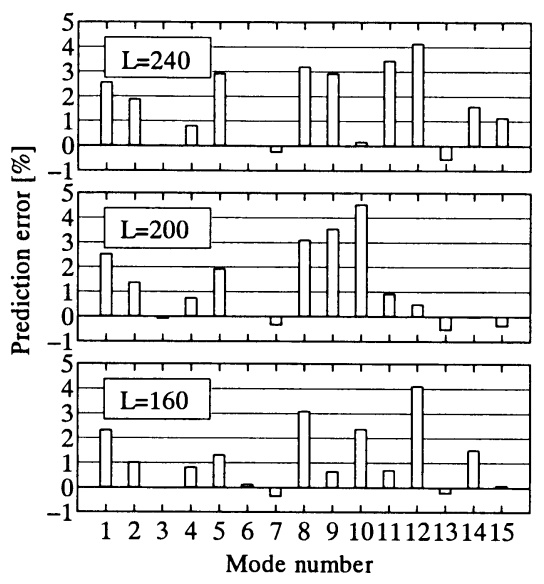

Fig.4 Errors in natural frequencies predicted by SDM using the exact mode shape data 
がって, SDM 法でリブ補強後の固有振動数を精度よ く予測できるといえる.

\section{$3 \cdot 2$ 部分モデルを用いたモード拡張 リブ取付} け面に垂直な方向の並進自由度データを参照し，未測 定点の実験デー夕を推定するときに，部分モデルを用 いることの可能性と部分モデルの境界条件の影響につ いて検討する．また，推定精度が高くなるときの重ね 合せる解析モードの数を決定するための指標として, モード行列の条件数を用いることの妥当性を調べる.

ここで用いた部分モデルを図 5 に示す．部分モデル はリブ取付け位置の詳細な検討が可能なように，平面 シェル要素を用いて Y 方向に細かく分割し， 231 節点 （21 節点 $\times 11$ 節点）を持つようにモデル化した. 材 料特性と板厚は全体モデルと同じである. 部分モデル の境界条件としては，典型的な境界条件として，次の 3 条件を検討した

・周辺自由：4 辺すべてで拘束なし

- 単純支持：Y 軸に平行な両端を単純支持

- 完全固定：Y 軸に平行な両端を完全固定

\section{$3 \cdot 2 \cdot 1$ 測定点数 21 点の場合 図 5 に示す $\mathrm{X}$ 方} 向 21 点, $\mathrm{Y}$ 方向 3 点の測定点において, $\mathrm{Z}$ 方向の並 進自由度データだけが測定されたと想定した. そのデ 一夕を参照し， 3 種類の境界条件で求めた解析モード を用いて, 1 次から 20 次までの 20 個のモードについ て 21 点 $\times 11$ 点における 6 自由度の振動モードデータ を推定した. モード抁張に用いる解析モードの数は, 10 から 40 まで 5 ずつ増やした. なお周辺自由の境界 条件では, 重ね合せる解析モードに 6 個の剛体モード を含めた。これは，前報 ${ }^{(5)}$ で剛体モードを含めない場 合には推定精度が悪くなったためである.

図 6 に重ね合せた解析モードの数に対する推定誤差 の変化を, 図 7 に条件数の変化を示す. 図 6 の縦軸は, 推定された振動モードデータと FEM 解析で求めた真 の実験データとの差である. その值は, 対応するモ一 ドごとに求めた成分間（モードごとに最大成分が 1 と なるように正規化）の差の絶対值和を, 成分の数で割 った值の 1 次から 20 次までの 20 個のモードの平均值 である. 横軸は, 測定点に対応する節点の $\mathrm{Z}$ 方向並 進自由度データがすべて 0 に近い（ここでは, モード 質量が 1 となるように正規化したときに絶対值が $1 \times$ $10^{-5}$ 以下になる）モードを除いたあとの重ね合せた解 析モードの数である. なお, 周辺自由の場合は剛体モ 一ドを含めた数である. 図 6 において，すべての境界 条件で推定誤差は重ね合せるモードの数の増加ととも に安定に減少していることがわかる，一方，条件数は ゆっくりと増加しているが，ここで用いた最大モード
数 40 まででは, それほど急激な増加は見られない. したがって，実験モードに測定誤差が含まれない場合 には，測定点と重ね合せる解析モードの関係で決まる 条件数が 10 を超えない程度の範囲では, 多くのモ一 ドを重ね合せることで推定精度が高くなるといえる.

部分モデルの境界条件が振動モードの推定精度に及 ぼす影響については, 各境界条件とも 40 個のモード を重ね合せたときの推定誤差の最小值を比較すると, 同程度である．したがって，顕著な違いは見られない．

$3 \cdot 2 \cdot 2$ 測定点数 11 点と 13 点の場合 図 8 に示 す2つの測定点セット（測定点数 11 点と 13 点）にお いて, $\mathrm{Z}$ 方向の並進自由度データだけが測定されたと 想定した. 推定するデー夕は, 前項と同じ 21 点 $\times 11$ 点での 6 自由度の振動モードデータである. 重ね合せ

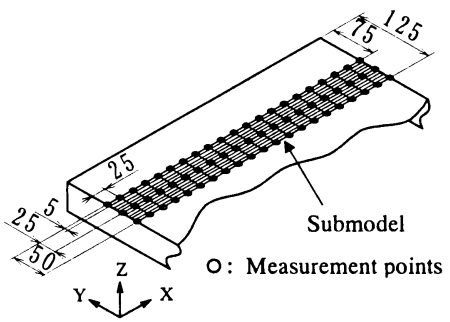

Fig.5 Submodel for the mode shape expnsion

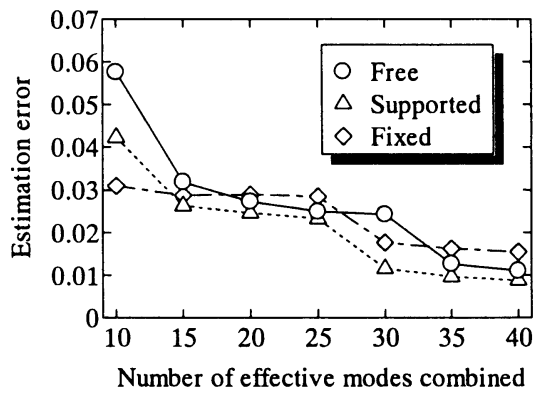

Fig.6 Errors in the estimated mode shape data (21 measurement points per line)

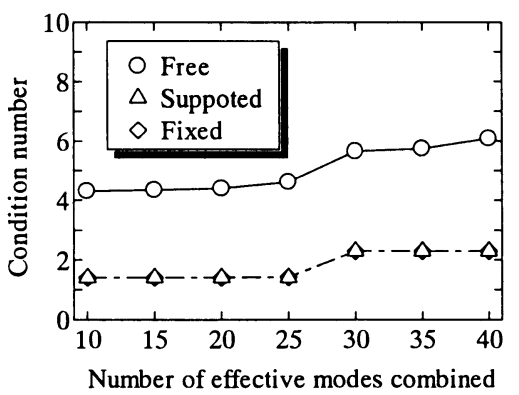

Fig.7 Condition numbers (21 measurement points per line) 
るモードの数は, 10 から 30 まで 2 ずつ増やした.

図 9 に推定誤差の変化を, 図 10 に条件数の変化を 示す. 図 9 において, 測定点数 11 と 13 のどちらの場 合もすべての境界条件で推定誤差は重ね合せるモード の数の增加とともに減少する. しかし, さらに重ね合 せるモードの数を增やすとすべての場合に推定誤差が それぞれの最小值になった後, 增加する傾向にあるこ とがわかる.これは, 前項の測定点数 21 の場合と大 きく異なる.したがって, 測定点数が少ない場合には, 推定精度を高くするためには適切な数の解析モードを 重ね合せる必要があり，そのためにモードの数を決め る必要があることがわかる.

図 9 と図 10 において, 例えば, 測定点数 13 で境界 条件が周辺自由の場合では, 重ね合せるモ一ドの数が 24 のときに推定誤差が最小となっている. 一方, 対

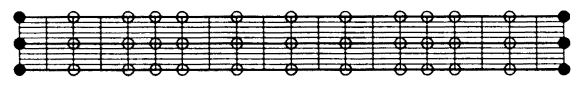

$0: 11$ measurement points per line O\& : 13 measurement points per line

Fig.8 Measurement points

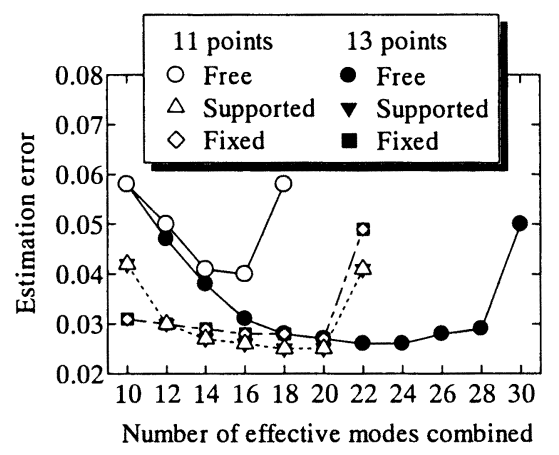

Fig.9 Errors in the estimated mode shape data (11 \& 13 measurement points per line)

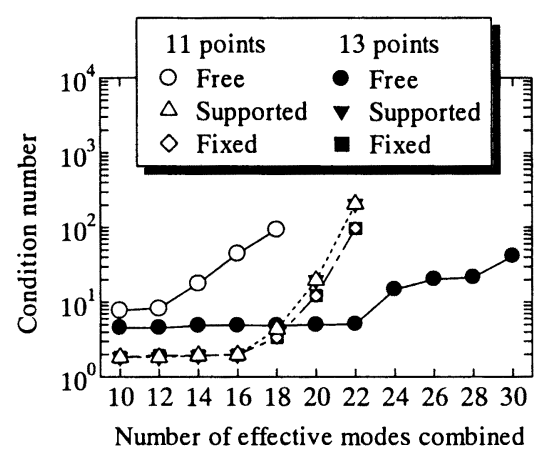

Fig.10 Condition numbers

(11 \& 13 measurement points per line)
応する条件数の変化は, 重ね合せるモードの数が 22 と 24 の間で急激に増加している. 他の場合も推定誤 差が最小となるときの重ね合せるモードの数の近傍で, 条件数が急激に増加する傾向にあることがわかる．し たがって, 条件数の変化を調べることで, 適切な重ね 合せるモードの数を決めることが可能だといえる.

測定点数が 11 で周辺自由の場合, 推定誤差の最小 值が他の場合と比べて大きくなっている. また, 重ね 合せるモードの数が少ないときから条件数も大きくな っている.これは周辺自由の場合, 図 8 の測定点数 11 では測定点数が不足しているために, 多くのモー ドを重ね合せることができず，推定誤差が大きくなっ たと考えられる. したがって，推定精度を高くするた めには多くのモードを重ね合せた方がよいが，そのた めには適切な数の測定点数が必要であるといえる.

部分モデルの境界条件が振動モードの推定精度に及 ぼす影響については, 測定点数が 13 の場合の各境界 条件の推定誤差の最小値を比較すると, 同程度である. したがって, 前項と同様に顕著な違いは見られない.

$3 \cdot 3$ 推定された実験モードを用いた SDM 前 節で推定した振動モードデータを用いて SDM 法で予 測計算を行い，モード拡張法の推定精度が SDM 法の 予測精度に及ぼす影響を調べる。ここで用いるデータ は, 測定点数 13 の場合に各境界条件で誤差が最小と なったときの振動モードデータとした.

ここでは, 推定された振動モードデータを用いた SDM 法の予測結果を $3 \cdot 1$ 節の FEM 解析で得られた 真の実験モードを用いた SDM 予測結果と比較した. $\mathrm{SDM}$ 予測計算は, $3 \cdot 1$ 節と同じ 1 次から 20 次までの 20 個のモードを用いて, リブ取付け間隔 $\mathrm{L}=160 \mathrm{~mm}$, $200 \mathrm{~mm}, 240 \mathrm{~mm}$ の 3 箅所について行った. L=160mm と $240 \mathrm{~mm}$ は, 図 3 に示す左側のリブの底面中央の結 合節点が図 5 の端からそれぞれ $120 \mathrm{~mm}$ と $80 \mathrm{~mm}$ の位 置になる（右側のリブも同様）ので, リブが測定点以 外の位置に取り付けられた場合に相当する.

図 11 に, 真の実験モードを用いた SDM 予測結果 との相対予測誤差を示す. 境界条件が周辺自由と単純 支持の場合は, リブ取付け間隔 $\mathrm{L}=200 \mathrm{~mm}$ の 1 次モ一 ドを除いて予測誤差が $2 \%$ 以下である. さらに, 各リ ブ取付け間隔における 15 モードの半分以上は, $1 \%$ 以 下の小さな誤差となっている. 境界条件が完全固定の 場合は, すべてのリブ取付け間隔の 4 次モードに予測 誤差の大きいものが見られるが, それを除けば周辺自 由, 単純支持の場合と同程度である. したがって, リ ブが測定点以外の位置に取り付けられた場合でも, 前 節で推定された振動モードデータを用いて真の実験デ 


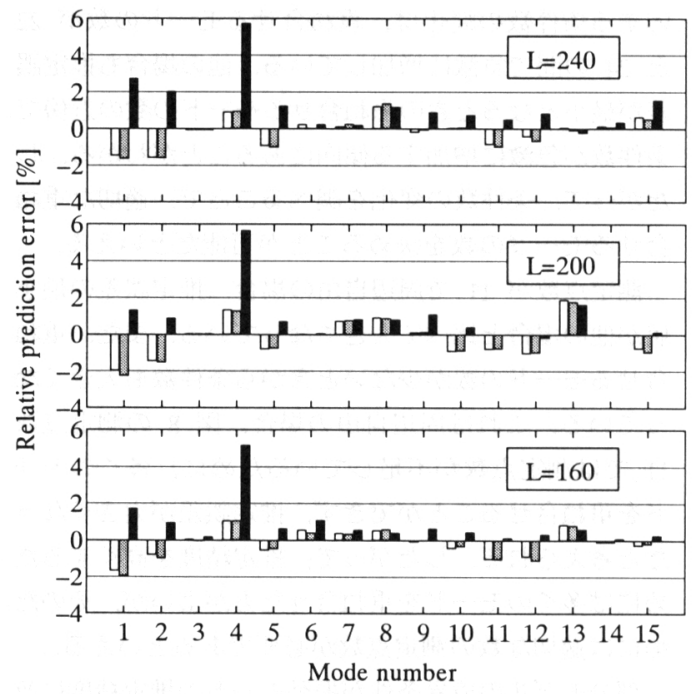

Fig.11 Relative errors in natural frequencies predicted by SDM using the estimated mode shape data

( $\square$ : free, $\square$ : supported and $\mathbf{\square}$ : fixed )

ータを用いた場合とほぼ同じ精度で固有振動数が予測 できているといえる.

以上のことより, 部分モデルを用いたモード拡張法 で実験データとして利用可能な振動モードデータが十 分に推定可能である. その結果, 補強リブが測定点以 外の位置に取り付けられた場合でも, 本報で提案する モード拡張法を組み込んだ補強リブ構造変更シミュレ ーション法で精度よくリブ補強後のモード特性が予測 可能であるといえる。

なお, 部分モデルの境界条件の影響は, 適切な数の 解析モードを重ね合せたときにはモード拡張さらに SDM 予測においてもそれほど大きくない. したがっ て, 設定の容易さからも部分モデルの境界条件として は周辺自由がよいと考えられる.

\section{4. 結 言}

本報では, 補強リブが測定点以外の位置に取り付け られた場合でも, 補強後のモード特性の予測が可能な 補強リブ構造変更シミュレーション法を提案した。測 定点以外のリブ取付け点の実験データを推定するため に，部分モデルを用いたモード拡張法を組み込んだ。 モード拡張法の推定精度を向上させるために, 重ね合 せる解析モードの数を決定するための指標として, 部 分モデルのモード行列の条件数を用いた. また, 部分 モデルの境界条件の影響についても検討した。

数值例で提案方法の有用性および境界条件の影響に ついて検討した結果，以下のことが明らかになった。
（1）補強リブが測定点以外の位置に取り付けられた 場合でも, 提案方法で精度よくリブ補強後のモード特 性が予測できる。

（2）部分モデルを用いたモード拡張法で, 実験デー 夕として利用可能な未測定点での振動モードデータが 十分に推定可能である. ただし，推定精度を高くする ためには多くのモードを重ね合せた方がよいが，その ためには適切な数の測定点数が必要である.

（3）モード抎張において，測定点数が少ない場合に は適切な数の解析モードを重ね合せる必要がある. そ のモードの数は, 部分モデルのモード行列の条件数の 変化を調べることで決定することが可能である.

（4）部分モデルの境界条件の影響は，モード拡張さ らに SDM 予測においてもそれほど大きくない。した がって, 設定の容易さからも部分モデルの境界条件と しては周辺自由がよい。

\section{謝辞}

本研究の一部は平成 $15 \cdot 16$ 年度文部科学省科学研 究費補助金 基盤研究 (C)（2）（課題番号 15560198）の 助成を受けたものである．記して謝意を表する.

\section{文献}

(1) Formenti, D. and Welaratna, S., Structural Dynamics Modification- An Extension to Modal Analysis, SAE paper No.811043, Oct.(1980).

(2) Tayeb, M.M. and Williams, E.J., Rib Stiffeners for Use in Structural Dynamics Modification, Proc. 6th International Modal Analysis Conference, (1988), 1094-1099.

(3) Wallack, P., Skoog, P. and Richardson, M., Comparison of Analytical and Experimental Rib Stiffener Modifications to a Structure, Proc. 7th International Modal Analysis Conference, (1989), 965-973.

(4) Schwarz, B.J. and Richardson, M.H., Structural Modifications using Higher Order Elements, Proc. 15th International Modal Analysis Conference, (1997), 313-318.

(5) 鞍谷文保·山野惟夫·小川武範，シェル要素でモデル化 された補強リブの構造変更シミュレーション, 機論, 68-676, C(2002), 3479-3485.

(6) O'Callahan, J., ほか 3 名, An Efficient Method of Determining Rotational Degrees of Freedom from Analytical and Experimental Modal Data, Proc. 4th International Modal Analysis Conference, (1986), 50-58.

(7) 鞍谷文保·岩壸卓三·冲田耕三, 数值解析の援用による 回転自由度モードの推定（重稀せるモードの選択に 関する検討），機論, 62-603, C(1996), 4205-4211.

(8) 中川 徹·小柳義夫, 最小二乗法による実験デー夕解析, (1989), 76, 東京大学出版会.

(9) Penny, J.E.T., Friswell, M.I. and Garvey, S.D., The Automatic Choice of Measurement Locations for Dynamic Testing, Proc. 10th International Modal Analysis Conference, (1992), 30-36.

(10) O'Callahan, J. and Li, P., An Automatic Selection of Reduced Degrees of Freedom, Proc. 12th International Modal Analysis Conference, (1994), 481-485. 